\title{
La imagen audiovisual en la vida contemporánea
}

\author{
Magdalena García Toledo \\ Departamento Académico de Comunicación Social
}

\begin{abstract}
A nuestra época se le llama la "civilización de la imagen». Y es porque está presente permanentemente en muestras vidas, casi no nos damos cuenta cuán rodeados y hasta en cierta forma cuán indefensos estamos ante una catapulta de imágenes de todo tipo. Se sabe quela imagen influye de manera significativa en nuestra manera de pensar y en nuestra percepción del mundo. Vale Iapena conoger algo acerca de ella.
\end{abstract}

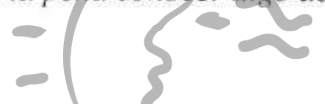

Para algunos la imagen constituye suerte de atmósfera cultural que han venido en denominar «iconósfera».

El entorno personal, famitiacefabora es poblado de afiches, pinturas,

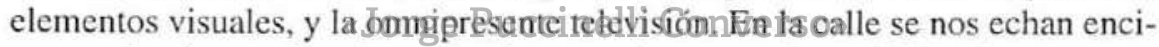
ma un sinnúmero de avisos, señales, carteles, anuncios publicitarios y propagandísticos, escaparates cada vez más refinados. El cine y la televisión nos mecen en imágenes de ensueño, erotismo y violencia. La publicidad nos ofrece las veinticuatro horas del día las esplendorosas imágenes del vivir más hedonista y del consumismo más exacerbado.

Al mismo tiempo, nuestro hogar se va a convertir -según los futurólogos, y parece que no les falta razón-en una especie de centro audiovisual que nos permitirá concentrar las tradicionales actividades de estudiar, trabajar y entretenerse. Las diferentes señales visuales que nos llegan del satélite, del cable, de la televisión abierta, del cine y del video comandados por una computadora universal, nos permitirá interrelacionarnos con el planeta entero, es decir, recibir y enviar imágenes, textos y sonidos. 
Tan presente está la imagen, que los teóricos no cesan de estudiarla, más ahora que se añade a ese inventario, la imagen virtual, tridimensional, que borrará los límites entre la realidad y la fantasía. Se habla incluso de una dictadura de la imagen, de un fetichismo,y hasta de una adicción que no se diferenciaría gran cosa de las otras.

Parece necesaria entonces una mirada más consciente y crítica a esa iconósfera de parte de los hombres y mujeres comunes y corrientes de nuestra época.

\section{La Imagen}

En sentido general, la imagen es la representación visual de un objeto o un hecho de la realidad o del mundo psíquico. Del latín imago, -representación, figuración-, la imagen siempre nos remite a un referente -el mundo-con el cual mantiene relaciones de analogía o semejanza perceptiva. Y de allí su peligro, porque tendemos a creerque la imagen de algo es la realidad misma, sin percatarnos que los hacedores de imágenes las manipulan (en el buen y en el peor sentido de la palabra) para ofrecernos a través de ellas su propia interpretación de la realidad.

Cuando se habla de imàgen publicitariā oggráfices, queda involucrado en tal concepto el texto escrito que la acompañan Aungue la imagen se presenta sola algunas veces, esto no es lo más común en la vida social. La imagen necesita de la palabra para precisar su significado y cumplir sus objetivos.

Lo que debe quedar muy claro -repetimos-es que la imagen es una representación de la realidad, nunca la realidad misma. Esto parece algo obvio. Sin embargo, mucho de lo que se le critica a los medios masivos tiene que ver con cierta incapacidad de algunos receptores (niños, personas de mentalidad infantil, de bajo nivel educativo, etc.) para diferenciar claramente entre lo que la realidad es y lo que presentan los Medios. Pero también encontramos la explicación en la retórica de los propios Medios, que les permiten manejar los ingentes recursos que poseen en la consecución de sus intereses publicitarios y económicos.

En este sentido, la imagen periodística - una fotografía por ejemplo- parece mostrarnos los hechos tal como sucedieron, pero definitivamente no es así. La imagen siempre es producto de una selección, de un punto de vista. 


\section{La Percepción}

Siendo la imagen una propuesta visual, el proceso de su percepción es una actividad humana que participa activamente en la construcción del sentido.

Ver es algo muy diferente a percibir. lo que vemos es lo mismo para cualquier persona que observa, pero no todas perciben lo mismo. La lingüística y la antropología han descubierto, por ejemplo, que el concepto "nieve» para el hombre occidental es uno, mientras que para el esquimal tiene más de veinte, es decir, éste último percibe más en función a su experiencia cultural.

Por eso es que la percepción es un fenómeno condicionado por la cultura y no es la misma en todas las agrupaciones humanas. La Escuela Gestáltica ha estudiado este fenómeno y ha descubierto lo siguiente;

- la percepción es activa y no pasiva; el ser humano pone en función, en diversos grados, los procesos de atención, comprensión, apropiación, y los estados emocionales que le suscita la percepción de la imagen;

- la percepción es global y no por elementos aislados; la mirada se dirige a los llamados «centros de interés» y como un péndulo los recorre;

- se percibe una figura y un fondo en la construcción estructural de la imagen; el fondo es el contexto đønde «actúa» la figura, formando ambos una unidad;

- la percepción tiende harganizarcyarelacionar los diversos objetos que coexisten en la imagen; cen, están cercanos o tienen algún elemento en común; igualmente, a alejar los objetos que se encuentran distanciados o son muy diferentes;

- la percepción tiende a buscar en toda imagen un orden, regularidad y simplicidad, y a completar con estas características las imágenes irregulares, desconocidas e incompletas;

- en este sentido, toda imagen común produce serenidad y toda imagen inesperada, tensión. De esto se valen los publicitarios y los profesionales de la imagen para crear el impacto como preámbulo al objetivo comunicacional;

- hay finalmente una tendencia, producto de la cultura, a leer la imagen de izquierda a derecha tal como se hace con un texto escrito.

Así pues, las leyes de la percepción y los condicionamientos culturales intervienen relevantemente para la lectura de la imagen. A esto habría que agregar el componente emocional que puede hacer variar la percepción y hasta a constituir un «ruido» comunicacional. 


\section{Características de la Imagen}

- Polisemia. Una imagen pura, sola, puede contener muchos significados potenciales; en esto se diferencia de la palabra que tiende a la precisión. Un rostro de expresión neutra puede ser interpretado en términos de «tristeza», «serenidad», «añoranza», «bondad», «seducción», «seriedad» y de otros modos posibles.

De allí que la imagen necesite de la palabra para poder precisar su significado, como decíamos antes. Aún en el arte, los cuadros y pinturas llevan un título o alguna referencia mínima. Cuánto más una fotografía periodística o una página publicitaria, las cuales necesitan en un caso informar y en otra persuadir muy claramente.

- Emocional. Muy pocas imágenes nos dejan indiferentes, la mayoría de ellas produce en nosotros alguna reacción emocional, de atracción o rechazo, conformidad o rebelión, el despertar de algún recuerdo, en general, fenómenos tan conocidos como la jentifieación y proyección.

Quizá esto explique también el femor que sienten algunas tribus en dejarse fotografiar, pues piensan que la cámara o imagen resultante les robará el alma.

Esta característicaino rios debe Hevaea Eonduieque la imagen es emocional ciento por ciento, yj la palabracacipnal. Noesasí. Una imagen documental puede ser bastante objetiva y fría y una poesía ser altamente emotiva y muy poco racional. Imagen y palabra no son antitéticas. Sin embargo la apreciación general de la imagen es la de ser más emocional que racional. En ello radica la falsa idea de que su lectura es muy fácil; sin embargo, al igual que la palabra, en la imagen encontramos niveles de interpretación que trascienden la simple percepción sensorial.

- Iconocidad. La imagen al representar algo tiene diferentes grados de «parecido» o semejanza con lo que representa. A esto llamamos iconicidad. La fotografía tiene un alto grado de iconicidad ya que permite a cualquiera, incluso a un niño pequeño, reconocer inmediatamente de lo que se trata. Son muy icónicos el cine, la televisión y el video. Lo son menos la ilustración, el dibujo, el esquema, un mapa, hasta llegar a la imagen abstracta.

Si en las primeras prácticamente no es necesario un código para la lectura de la imagen por la íntima analogía entre ésta y su referente, en la imagen abs- 
tracta, en cambio muy convencionalizada, necesitamos del código para la interpretación.

La imagen es además concreta y está en tiempo presente. Cuando vemos la imagen de un niño, siempre es un niño particular, con rasgos físicos y raciales concretos, de una edad determinada, vestido también de una manera determinada, y en un contexto también específico. La imagen propone algo en tiempo presente, no como la palabra que puede referirse al pasado o al futuro. Sin embargo cuando la imagen es narrativa -como en el caso de la historieta o del cine y la televisión-, existen imagénes precedentes y posteriores que asumen aquellos tiempos verbales.

\section{Funciones de la Imagen}

- Representativa. La primera función de la imagen es representar la realidad. Es una función denotativa, que cumple con-diversos niveles de iconicidad. La imagen documental televisiva y la fotografía son ejemplos de ello.

- Informativa. La imagen nos entrega gran cantidad de información del mundo. La imagen periodística nos narra un acontecimiento con una cantidad de detalles que no solemos encontrar en la noticia escrita.

- Estética. Aunque no puede considerársela comunicativa en un ciento por

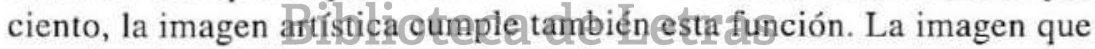
trasmiten los Medios de Comunicación buscan cada yez más niveles estéticos en sus propuestas. En algunos casos, la imagen publicitaria y la imagen gráfica pueden ser consideradas artísticas.

- Apelativa. Muchas imágenes se dirigen al receptor para indicarle algo. Las imagénes publicitarias y propagandísticas son apelativas por excelencia. En ellas, el receptor es señalado y conminado a mirar y atender algo con miras a activar una emoción.

- Simbólica. En el polo de la función representativa, la imagen simbólica es arbitraria, es decir obedece a una convención cultural para su lectura. Son las señalizaciones de carretera, los símbolos de restaurante, teléfono, correo, los relativos al sexo masculino y femenino, el signo de no fumar, las banderas, la cruz, Cupido. El repertorio de imágenes en nuestra cultura es amplio y casi todo el mundo sabe interpretarlas y comunicarse a través de ellas. 


\section{Clases de Imagen}

No es fácil hacer una clasificación de imágenes, por su gran variedad de presentación y funciones. Sin embargo, desde el punto de vista comunicativo, que es el que nos interesa, la imagen se manifiesta, por su importancia, de la siguiente manera:

- la imagen publicitaria: es abundante en la televisión y radio, en afiches y grandes carteles, en diarios y revistas;

- la imagen fotográfica: la encontramos en la televisión, el cine, el video, en los periódicos y revistas;

- la imagen gráfica: en libros, revistas, periódicos, logotipos, marcas, mapas, diagramas y en la estadística.

\section{La Industria de la Imagen}

El gran consumo actual de la imagen tiene mucho que ver con el carácter industrial de su producción a través de los complejos audiovisual, editorial y gráfico respectivamente.

El profesional por exceleneì principalmente de la imagen gráfica y editorial es el diseñador gráfico, responsable de la organización y proyección de

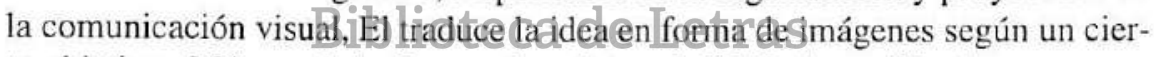
to objetivo. Más que ladellęza-e elicarácter, el dideñador gráfico busca con su producto la coherencia formal y sobre todo la funcionalidad.

Las actividades que coordina son las relativas a la imprenta, la actividad editorial y la publicidad. La característica fundamental de su trabajo es la reproducción en serie, para una gran cantidad de público.

El proceso que sigue el diseñador gráfico es el siguiente (imaginemos la realización de un afiche promocional para un cantante de rock):

- contratación de una agencia publicitaria, la cual contará con un presupuesto determinado, casi siempre muy alto;

- recolección y selección de datos sobre el cantante, su actividad, la imagen que quiere proyectar, su posible vestimenta, peinado, maquillaje, y el contexto donde se le situará; 
- elaboración del boceto, donde convergen diversas técnicas, diseños y creatividad, y cuyo fin es atraer instantáneamente la atención del público; el texto es breve, mientras más lejos esté el afiche, menos palabras requerirá, este boceto es sometido a la aprobación del cliente;

- diseño del original, el boceto elegido se completa;

- elaboración de matrices;

- impresión;

- distribución del afiche en lugares idóneos, revistas musicales y de espectáculos, discotecas, avenidas y calles, etc.

\section{El significante en la Imagen}

Una cuestión fundamental en la lectura de la imagen es el impacto que debe suscitar en el receptor. Ese impacto se apoya principalmente en el carácter sensible de la imagen, en lo que es percibido por el sentido de la vista y que tiene que ver con el color, la luz, la composición entre otros. Este es el «significante» de la imagen, la materia de la expresión. A través del significante se van a traducir las ideas, conceptos, el «mensaje» en una palabra.

Manejar el significante para los hacedores de imagen es muy importante, pensemos en el mensaje publicitario que debe ser breve, sencillo, atractivo, impactante y sobre todo muy claro f eomprensfvo para los destinatarios. Los recursos humanos, artístiebsy finandiefos noserann mutica suficientes si no se logra el objetivo de explicitar perfectamente lo que se desea. Lo mismo puede decirse de la propaganda política. Los elementos básicos del significante que manejan los profesionales de la industria de la imagen son los siguientes:

\section{a. El Punto}

Es la unidad mínima de la comunicación visual, signo redondo que puede presentar varias dimensiones y de gran atracción para el ojo. Producto del contacto de un lápiz, pincel u otro material en una superficie. Un conjunto de puntos, combinados de diferentes formas, pueden constituir un mensaje visual. Recordemos el estilo puntillista en pintura. La fotografía, suficientemente ampliada, se percibe como un conjunto de puntos de diferentes tonos y densidades que vistas globalmente configuran la imagen. 


\section{b. La Linea}

Es el elemento visual por excelencia del boceto o dibujo. «el punto en movimiento" o la unión de puntos sin que haya distancia entre uno y otro. La línea es dinámica, siempre se dirige a algún sitio. Permite prefigurar algo que sólo se tenia en la imaginación, pero reduciéndola a sus formas esenciales. Según la dirección, la línea puede ser:

- horizontal, dando una sensación de serenidad y estabilidad (la referencia es el cuerpo humano en reposo);

- vertical. Trasmite la sensación de tensión, fuerza (es el ser humano de pie, erguido, listo a la acción, proyectándose hacia arriba);

- oblicua, está a medio camino entre la línea horizontal y la vertical; es una posición imposible para el ser humano, por eso mismo, esta línea dá sensación de inestabilidad, de «amenaza»;

- curva, se asocia con ideass de movimiento, calidez, suavidad, repetición.

Las líneas-fuerza se determinan no sólo por la dirección y movimiento de la línea, sino también por la forma y el color. En toda imagen podemos encontrarlas imponiéndose a la percepción y contribuyendo a dar a la imagen impresiones de dinamismo, tensión, serenidad, movimiento. Por ejemplo, las imágenes fotográficas o publicitarias que quieren comunicar sensaciones de serenidad y reposo recurren a paisajes o a la umagen de mar, mostrándolas en su horizontalidad. Lo mismo puede decirse de las imángenes que quieren trasmitir ideas de fuerza y tensión: personas, árboles, edificios o cosas que se yerguen verticalmente.

\section{c. El Contorno}

Resulta de la línea dando forma a algo. Hay tres contornos básicos a partir de los cuales pueden construirse muchos otros asociados a las formas de la naturaleza y a la ilimitada imaginación del ser humano:

- el cuadrado, crea sensación de rectitud, formalidad, honestidad;

- el triángulo, se asocia con ideas de tensión y dinamismo;

- el círculo, es la calidez, la infinitud, la inocencia. 


\section{d. La Luz}

Elemento importante de la imagen, permite distinguir en ella la claridadoscuridad y los tonos que como una escala recorren estos dos polos. Se habla de la escala de grises cuando la imagen es en blanco y negro; y de tonos en general cuando la imagen es a color. Esta propiedad de la luz contribuye a la creación de la dimensionalidad de los objetos y a la percepción de las distancias, la profundidad y las relaciones entre objetos y ambiente.

La luz permite construir imágenes poéticamente iluminadas, otras muy oscuras y sombrías, y también ambientes fuertemente contrastados de luz y sombras; con ello se crean sentimientos y emociones que imprimen a la imagen fuertes connotaciones.

La imagen publicitaria, por ejemplo, maneja magistralmente este recurso, y lo mismo podemos decir del cine y la televisión. La escuela expresionista del cine alemán y muchas películas de corte psicológico y de terror conceden la debida importancia a este elemento.

Hay algunas formas de iluminar un objeto según diversas situaciones. Son conocidas en televisión y cine las siguientes:

- luz de frente, que ilumina frontalmente al objeto, resaltándolo y enfocándolo;

- luz de lado, crea la sensacion de volumen, resaltando un lado del rostro y cuerpo del sujeto.

- contraluz, el sujeto es iluminado por la parte de atrás dejando al frente en sombras;

- luz de arriba, contribuye a resaltar el cabello y la frente del sujeto, esculpiéndolos. Así mismo, con intención expresiva, el rostro puede presentar zonas iluminadas y zonas en sombras muy sugerentes.

\section{e. El Color}

Es uno de los elementos visuales de mayor y más profunda incidencia emocional. La imagen desde sus comienzos hasta nuestros días ha intentado por diversos medios y técnicas reproducir la amplia y variada gama de colores de la naturaleza. En la actualidad el color se ha impuesto sobre todo en la television y el cine, conservando el blanco/negro para propósitos históricos y documentales. 
Los colores se pueden agrupar de muchas formas. Una clasificación común dentro del terreno de la imagen comunicativa es la siguiente:

- Los colores cálidos. Respecto a conceptos tales como temperatura y distancia, están asociados a sensaciones como calidez y cercanía; son los llamados colores tierra, naranjas, y beiges.

- Los colores fríos. Crean sensaciones de distancia y frescura; son la gama de los azules y verdes.

En el campo de la creación visual, encontramos atractivas combinaciones entre ambos tipos buscando ciertos contrastes. En la televisión por ejemplo es común observar sobre una escenografía de colores fríos locutores con ropas y accesorios de colores cálidos.

En general, la comunicación visual busca comunicar estados de ánimo o propiciarlos a través del uso del color. Así:

- el color rojo está ligado a la idea del fuego, de la pasión, el amor, lo erótico, el odio y el furor; pero también el peligro, la violencia;

- el color verde se adscribe con la frescura, la serenidad, la primavera, el renacer; pero también con Ta envidia;

- el color amarillo con la luz solar, lo brillante, lo expansivo, el calor; también significa traición;

- el color blanco esflaburezadanieverel fríot tadelicadeza.

Estas son tendenciagegeneraies gl hó debēinos $@$ lvidar que el color es un asunto al final muy personal, por lo que depende de cada persona su preferencia e interpretación.

\section{f. La Textura}

Es la cualidad óptica de la superficie de la imagen que se corresponde con el sentido del tacto. Es el «grano», la «tesitura» o «trama» de la imagen. Las posibilidades técnicas de creación y reproducción de la imagen tienden cada vez más al realismo, sobre todo en la fotografía, y se prevé en el futuro que junto con el volumen y el tamaño, este realismo se desarrolle más.

La textura está determinada por elementos diminutos que se repiten en la superficie mimando la composición de la sustancia, percibidos ópticamente. 


\section{g. La Composición}

Todos los elementos de la imagen que hemos estudiado hasta aquí confluyen en una propuesta global de imagen. La composición es así la organización de esos elementos de tal manera que atraiga la mirada con un fin comunicativo determinado. La imagen es una estructura.

Todos los elementos que se dan en la imagen se interrelacionan de muchas maneras: la luz puede hacer variar los contornos de un objeto, la proximidad de un color puede modificar a otro; la presencia de un objeto, variar la percepción del tamaño del siguiente.

Existen ciertos principios o leyes que gobiernan la composición de la imagen. Sin intentar profundizarlos, veamos algunas relaciones que se establecen entre los elementos de la imagen.

\section{h. El Equilibrio y el Peso}

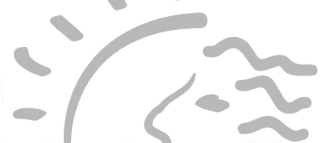

A nivel natural, el equilibrio es la sensación del hombre cuando se asienta sobre sus dos pies. Esta sensación se traslada a la imagen donde el receptor la busca inconscientemente. Una înagen equilibrada se percibe como la actuación de fuerzas que se compensan mutuamente, alrededor de un eje vertical imaginario.

\section{Biblioteca de Letras}

El equilibrio en la imagen depende del peso de los elementos; los objetos grandes pesan más que los pequeños; los colores claros, más que los oscuros; los objetos colocados en la parte superior de la imagen, más que los colocados en la parte inferior (por la ley de gravitación). El peso de un objeto colocado en el centro está equilibrado.

\section{i. El Contraste}

Para algunos comunicadores visuales, el contraste es la unidad mínima de la imagen, a la manera que lo son las letras y sílabas en el lenguaje. Para otros es una técnica o un recurso visual. Cualquiera que sea su estatus, el contraste es cuestión fundamental de la imagen. Una de las formas de crear significado es por el contrastre de personajes, hechos, situaciones, ideas, sentimientos. En la imagen es igual. Cómo encontramos el contraste en la imagen?: 
- contraste en la composición: armonía o desarmonía de los elementos visuales; simetría o asimetría;

- contraste en el tamaño y forma de los objetos;

- contraste en la luz, claro-oscuro;

- contraste de tonos,

- contraste de colores.

\section{j. La Escala}

Se refiere al tamaño relativo que adquieren los objetos de la imagen en sus relaciones recíprocas. Los juzgamos grandes, medianos y pequeños según ciertas claves: la propia experiencia de la realidad y la comparación de tamaños de los objetos dentro de la imagen. Esto sucede, por ejemplo, cuando observamos una imagen de edificios y casas. Al entrar «a cuadro» el presentador nos damos cuenta que se trata de una maqueta. Es así como muchas veces se trabaja en el cine y la televisión, y en ello radica su magia.

El hombre es entonces la medida para establecer la escala de los seres y las cosas. En este elemento los comunicadores visuales tienen un recurso para la manipulación del espacio de la imagen.

\section{Biblioteca de Letras}

k. La Perspectiva "Jorge Puccinelli Converso»

Aunque la imagen es estrictamente bidimensional, el ojo humano otorga profundidad a la imagen haciéndola tridimensional, sobre todo en la fotografía. Las luces y sombras, los tonos, los colores, contribuyen a crear esta ilusión.

\section{El Significado en la Imagen}

La construcción del significado es un fenómeno complejo donde intervienen la propia percepción del destinatario, la interpretación sensible de la imagen, su dotación psicológica y el contexto social y cultural donde actúa.

De los estudios de John Fiske, tomamos los siguientes criterios para la construcción del significado de la imagen: 


\section{- Por relaciones paradigmáticas}

Es muy común en la imagen publicitaria encontrar que al lado de los productos cosméticos, vestidos, perfumes, muebles, carros, bebidas, etc., se coloque siempre una imagen de mujer joven, bella, blanca y sexy. Pero, qué sucedería si en lugar de ella viésemos una mujer madura, gruesa y más o menos atractiva, es decir, una mujer como muchas?

En la relación paradigmática, la mujer joven y la mujer madura pertenecen al paradigma «mujer» que puede contener por supuesto otros tipos de mujer. En nuestra cultura la imagen de la mujer joven se asocia al mito de la juventud eterna, la belleza, felicidad y sexualidad. En cambio, la mujer madura está devaluada en esos términos.

¿Qué es un paradigma? Es un conjunto del cual se hace una selección y sólo una. El conjunto está constituido por unidades que presentan rasgos definidos y claramente diferenciables. En la imagen publicitaria que hemos descrito muy esquemáticamente, la selección de "mujer joven, bella y sexy» se ha hecho del conjunto o paradigma «mujer».

En este tipo de significación la selección no es pues una cuestión de estética o de azar, sino algo que obedece perfectamente a una racionalidad. «Donde hay selección hay significądo, y el significado de lo que seleccionamos está determinado por el significadodequen oselecoionamos» dice Saussure.

\section{- Por relaciones sintagmáticas}

"Jorge Pulccinelli Converso»

El sintagma es la combinación de unidades de paradigmas, y cómo cada una de estas unidades pierde su "sentido» original para verse afectado por la vecindad de los otros. Consideremos muy sucintamente una fotografía periodística.

Un conjunto de personas en primer término dando una conferencia de prensa, al fondo en la pared se aprecia el símbolo del Movimiento Revolucionario Túpac Amaru.

El análisis es muy sencillo. El símbolo político «tiñe» la percepción de las personas de manera muy diferente a si las viéramos con otros símbolos o simplemente no se viera nada. Se produce rechazo o simpatía, muy pocas veces indiferencia. 
La función persuasiva es propia del discurso codificado por las retóricas. En la antigüedad, la retórica era la argumentación, es decir una serie de artificios que daban al discurso un carácter original, revelando información inesperada y por tanto eficaz para los propósitos de la comunicación.

Entre estos artificios, la metáfora y la metonimia se constituyen como las más importantes en la construcción de la imagen. Ellas configuran las relaciones paradigmáticas y sintagmáticas respectivamente en la construcción del significado.

\section{- Por relación metafórica}

Tomemos otro ejemplo de la publicidad televisiva para entender esta noción. Sobre una imagen de una rosa que se ve fresca y suave se «sobreimpone» el rostro de una mujer con el cutis igualmente fresco y sonrosado. A continuación se anuncia la marca de un humectante.

El análisis formal nos permite detectar a nivel retórico una figura que desde el campo literario al de los medios de comunicación llamamos metáfora.

Dicho sencillamente, la operación metafórica consiste en la traslación del significado de una imagen a otra, de tal manera que ilustra eficazmente lo que la publicidad quiere significar: «si usas el humectante X, tu cutis será como el de una rosa». Este es un ejemplo muy elemental de metáfora visual, pero basta para entenderla.

\section{- Por relación metonímica}

Para desarrollar este punto tomaremos un ejemplo de la prensa local de hace algún tiempo. Fotografías acompañando artículos donde se mostraban a estudiantes universitarios protagonizando escenas violentas por protestas de diverso origen: subida de pensiones, de pasajes, etc.

La recurrencia de ese tipo de noticias que privilegia la violencia como valor noticioso y el acostumbramiento de los lectores a su lectura, fue creando la falsa imagen de que la universidad era un centro de proselitismo político y adoctrinamiento subversivo, y no como lo es verdaderamente, un centro de estudios y creación del saber. Ultimamente, sin embargo, está variando esta percepción de los estudiantes universitarios. La cuestión es que las noticias sobre actividades académicas, producción de conocimientos, actividades institucionales, no "vende». En cambio sí lo hace la violencia y el sensacionalismo. 
Estamos ante la presencia de una metonimia, es decir, un recurso por medio del cual se nombra la realidad de una manera diferente, se representa el todo por una parte y viceversa.

Lo importante es que la selección de una metonimia determina cómo construimos el resto del hecho a partir de la imagen. Este es un trabajo típico de los signos-índice que nos remiten de una cosa a otra. Por eso es un recurso poderoso que hace aparecer lo mostrado por los Medios como lo real y verdadero.

\section{- Por relación denotativa}

La construcción del significado de la imagen no se agota en el mensaje mismo sino en su «negociación con el receptor/lector. El es quien desde su propia situación concreta y a partir de ciertos condicionantes subjetivos, sociales y culturales, completa el ciclo de la significación. Uno de esos procesos fundamentales es el de la denotación.

Este concepto se refiere a la relación directa, unívoca, del signo con la realidad que representa, es decir, entre el significante y el significado.

En una imagen fotográfica, lo denotativo está conformado por los sujetos y elementos concretos, es decir por lo que se observa de ella objetivamente. También la consideración de las maneras conque ha sido fotografiado el objeto o hecho.

La denotación es el qué de la imagen, lo que «dice. Este nivel de la significación se presenta en los códigos matemáticos, técnicos y científicos, no así estrictamente en los culturales.

\section{- Por relación connotativa}

La connotación es la relación subjetiva, multívoca, indirecta, entre el signo y el lector. Surge de la interacción entre el signo y los sentimientos, emociones, actitudes, maneras de ver el mundo. Es decir, de sus vivencias psicológicas y los valores compartidos de su cultura.

En el ejemplo de la fotografía, lo connotativo está referido al punto de vista con el cual se realiza el "tratamiento» visual, es decir, la selección de un fragmento de la realidad, que ya es una decisión subjetiva o ideológica, y la manera cómo es presentado al lector a través del uso de planos, ángulos, foco, color, tamaño, encuadre. 
La connotación no sólo se da al nivel mismo del mensaje sino también en el encuentro entre la propuesta visual y el complejo psico-biológico-cultural que representa el lector.

Son connotativos el acento y el tono en el habla, los gestos y movimientos del rostro y del cuerpo, dentro de la comunicación presencial. De más está decir que los medios de comunicación no construyen la significación de manera neutral y esperan la misma correspondencia de parte del destinatario.

La connotación muchas veces funciona a nivel inconsciente y por lo tanto pueden pasar desapercibidas ciertas proposiciones cubiertas del ropaje de la denotación. Las cosas parecen naturales, objetivas, fácilmente digeribles, sobre todo a nivel del entretenimiento. Se hace necesario pues el análisis crítico de la imagen que trascienda la simple consideración de lo formal y denotativo.

\section{- El Mito}

Los Medios de Comunicación Masiva son portadores de mitos, los refuerzan y si es necesario los crean. Lo común sin embargo es que ya existan en la sociedad en la cual actúan.

En el sentido comunicativo, el mito no es una cuestión de falsedad o verdad, sino la manera cómo la sociedad conceptualiza ciertos valores, cómo entiende los grandes asuntosique pe preocupan. Sonn por lo tanto construcciones culturales o cadenas fopceptuales acerca de la naturaleza y la realidad.

Todas las culturas tienen mitos y la cultura occidental por su propia complejidad abunda en ellos. Pero los mitos no son universales sino específicos a cada cultura y van cambiando según la evolución social.

Los mitos más conocidos de nuestra cultura son: la objetividad de la ciencia, la superioridad de la razón, la inferioridad de la mujer, la inutilidad del anciano, la inmutabilidad del orden social, la fuerza de la ley y el orden, entre otros. En la actualidad se han desarrollado otros, convenientemente reforzados por la publicidad, relacionados con la salud, el cuerpo, la felicidad...

La interiorización de los mitos y el compartirlos culturalmente favorece la lectura connotativa de los mensajes mediales y de la comunicación en general. 


\section{- Los Símbolos}

Un signo se convierte en símbolo cuando significa algo muy diferente a lo que denotativamente está representando. La convención y el uso le permiten asumir esta representación.

Así como los mitos, los símbolos existen en la sociedad y son usados por los Medios, pero también éstos los crean y recrean, como hemos dicho. Así, por ejemplo, un desierto en una imagen fotográfica, televisiva o cinematográfica, puede simbolizar el aislamiento, la aridez, la desolación; asimismo el mar puede asumir una connotación de inmensidad, misterio y belleza. Las imágenes, en general, nos remiten permanentemente a diferentes símbolos. De esta manera, la imagen actúa en forma metonímica.

\section{- La Ideología}

Los significados connotativos los mitos y los símbolos surgen de un fondo común: la ideología.

La ideología es vista como el sistema de creencias características de una clase o grupo social, así come el proceso de producción de ideas. La percepción más generalizada de ideología es la que se refiere a la falsa conciencia, es decir, al sistema de ideas falsas o ilusorias con las que una clase domina a otra.

La ideología se vale de algunas instituciones para la transmisión de sus contenidos: la educacion, fa politica, la familia, y por" supuesto, los medios masivos de comunicación.

Existen ideologías dominantes y subalternas que subsisten en perfecto equilibrio. Los medios de comunicación se ocupan preferentemente de los primeros, aunque absorben y neutralizan a los segundos. En este sentido, se habla de una lectura preferente de los medios que corresponde a la ideología dominante, y lecturas subordinadas que corresponden a las ideologías subalternas.

\section{La Imagen Publicitaria}

Es acaso la imagen por excelencia de nuestra época y su vehículo natural es la televisión, tan natural que se ha afirmado que la televisión es un simple pretexto para la publicidad. 
La tremenda competencia originada por una producción industrial que rebasa ampliamente la demanda, ha permitido que la publicidad se desarrolle como lo ha hecho - a partir del aporte de la investigación científico, sobre todo de la psicología-, y la inversión astronómica que en algunos casos supera a la deuda externa de algunos países subdesarrollados. Este desarrollo continuará en el futuro, amenazando la autonomía cultural de estos países, a través de una transnacionalización creciente que envuelve además el campo de la informática y las nuevas tecnologías de la comunicación.

La sociedad de consumo podría encontrar su explicación en esta suerte de «ideología de la publicidad, donde la felicidad del ser humano sólo se encontraría en el consumo de los productos y servicios que nuestra moderna sociedad industrial nos propone, procedente, principalmente, de los países desarrollados. Un examen atento de nuestra televisión local confirma esta aserción, así como el surgimiento y rápido apogeo de profesiones ligadas al campo de la publicidad y el marketing.

La publicidad televisiva en nuestros paises muestra como un ideal de vida, sobre todo para la juventud, un estilo donde confluyen ropas ligeras e informales, comidas rápidas, molls gigantescos, bebidas gaseosas, computadoras y videos, carreras cortas que no demanden demasiado esfuerzo pero sí procuren dinero, y una vida fácil y cómoda, sin preocupaciones ni honduras. En fin, el correlato ideológico que acompaña el fenómeno neoliberal de nuestros días.

La publicidad, Ias telacionespúblicas, las entetastas de opinión y la inves-

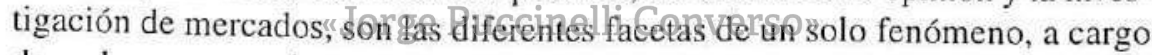
de poderosas agencias que frecuentemente controlan los sistemas nacionales de comunicación de los países en desarrollo. Su superioridad tecnológica, los ingentes capitales conque cuentan y su influencia en los niveles decisorios, les permite esto.

Contrariamente a otros sistemas de comunicación que declaran explícitamente sus fines informativos, educativos y culturales (aunque la realidad sea otra), la publicidad es la única en reconocer la ganancia como objetivo último. Y en este sentido, todos los procedimientos y técnicas que emplea están dirigidos a este fin supremo. La investigación psicológica le ha permitido implementar estrategias de persuasión a través de la imagen que están en la base de su razón de ser.

El modelo estímulo-respuesta-reforzamiento del conductismo, algunos principios gestálticos y el conocimiento del inconsciente que aporte el psicoanálisis, son las fuentes que nutren esas estrategias persuasivas. 
Pero no basta el conocimiento psicológico para el quehacer publicitario, son necesarias también un dominio de las diferentes técnicas que gobiernan los lenguajes audiovisuales, y sobre todo la existencia de complejas organizaciones como son la empresa y la agencia publicitaria.

La agencia tiene como función informar y persuadir al público sobre la existencia y posibilidad de compra de diferentes productos y servicios, y esto lo hace a través de la investigación del mercado y la producción de campañas y mensajes publicitarios.

La creación de los mensajes conlleva un dominio absoluto del lenguaje de la publicidad. Este lenguaje ha sido asociado al poder, por su capacidad de influir decisivamente en el comportamiento humano.

El lenguaje publicitario se explícita a través de sus funciones informativa y motivacional. La función informativa, denotativa u objetiva, tiene como objetivo entregar datos que informen al futuro usuario de las características reales o beneficios del producto o servicio. Ejemplo de ello es la publicidad médica.

La función motivacional, connotativa o subjetiva, es la típica de la publicidad comercial, tiene como objetivo actualizar o crear una necesidad relacionando ésta con el consumo. Es rica en significados inferidos, juega mucho con las emociones, intentacrearimágenes que se posicionen en la mente de los consumidores. Apela a las motivaciones más profundas del ser humano, como aquellas relacionadas al sexo, al afimento, abrigo, seguridad y afirmación de la persona.

El mensaje publicitario tiene como basamento imprescindible a la imagen, la cual es fundamentalmente fática e implicativa. Busca el impacto perceptivo, y para ello se vale de una hiperbolización de la imagen, dada por su tamaño, ángulo, color, iluminación, nitidez, contraste y el movimiento al cual se une el ritmo y el acompañamiento sonoro también efectista. Todo este esfuerzo redundante está dirigido a llamar la atención y mantenerla, aunque sea por breves segundos. Pero a la publicidad también le interesa asegurar la lectura precisa del significado. Así, la estrategia retórica acude para cumplir un importante papel.

Son cuatro las estrategias retóricas que abundan en la publicidad. La primera de ellas que denominaremos esencia tiene como finalidad presentar al producto solo, con la autoridad y dignidad que le da su posición en la imagen 
y el prestigio de la marca. Casi siempre en un primer plano, bien iluminado, con un fondo que no compita con él, con un color y nitidez que lo distingan, en un monopolio del espacio que hace prescindible a la palabra. No hay presentador, argumento, decoración, a veces ni eslogan, que distraigan la concentración de la mirada en el producto.

La metáfora es el recurso retórico por excelencia, en el cual un hecho o un objeto es presentado como símbolo o metáfora de un producto. Con esto se añade un valor determinado a la imagen. El análisis debe desentrañar si realmente esos valores se corresponden con los supuestos beneficios o características de los productos. La publicidad en este sentido es maestra en asimilar los movimientos culturales y preocupaciones de la época para sus fines: la liberación de la mujer, la preocupación ecológica, la revolución tecnotrónica, los movimientos juveniles.

La sinécdoque es la selecciôn pertinente de una parte para representar el todo realizando la connotación. El leetor completa el sentido global del mensaje a partir de esa selección. Una mano sofisticata con un brazalete de diamantes sosteniendo un vaso de licor, está fiñendo fuertemente la imagen de sofisticación, estatus social y erotismo.

La metonimia, como figura típica del relato, permite transferencias asociativas de una realidad a otra a partir de elementos concretos. Por ejemplo, una imagen de un dormitoriddonde tse ceenterimeerlang gna camisa masculina, se escucha música sensual y risas y murmullos en «pf „, (no se ven los personajes), deja a la imaginación de cada cual completar la historia.

\section{Una Educación para la Imagen}

Hemos visto cómo se manipula y se crea la imagen y cuántos procesos complejos subyacen en su construcción. Las imágenes publicitarias, televisivas y cinematográficas, aunque manejan sus propios lenguajes, no dejan por ello de apelar a esos procesos y de hacerse por ello susceptibles de análisis en cuanto a sus implicaciones retóricas y por lo tanto persuasivas.

Todo esto amerita una educación para la imagen que los agentes socializadores como la familia y la escuela deben encarar. En este trabajo se ha pretendido demostrar que la imagen no es una simple traducción de la realidad y por lo tanto de fácil lectura. No existe para nada esa transparecencia. Hay demasiado en juego para aceptar esa interesada afirmación. 
Las investigaciones de consumo de Medios en nuestro país nos indican que la gente pasa ante el televisor un tiempo que muchas veces puede ser equiparado al de la escuela. Esto sucede principalmente en las clases económicamente desfavorecidas, que han centrado su tiempo de ocio en el entretenimiento televisivo. Se sabe que mientras menos educada sea una persona o más susceptible de influencia, las propuestas de los Medios -especialmente la televisión-serán recepcionadas sin mayores resistencias, y sin los elementos críticos que opongan los legítimos intereses y necesidades de las personas.

Urge entonces una pedagogía de la imagen, una educación para los medios de comunicación, que dote a las personas de esa capacidad crítica que las haga sujetos autónomos y no objetos de manipulación.

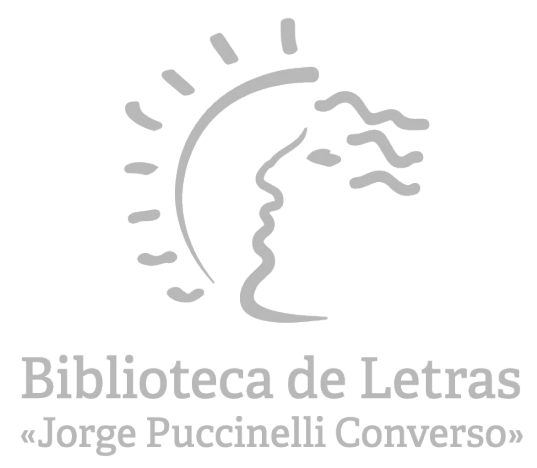




\section{BIBLIOGRAFIA CITADA}

ECO, Umberto

La estructura ausente. Introducción a la Semiótica. Editorial Lumen, Barcelona, 1975.

FISKE, John

Introducción al Estudio de la Comunicación. Editorial Norma, Bogotá, 1984.

INSTITUTO PARA AMERICA LATINA (IPAL)

Publicidad, la otra cultura. IPAL, Lima, 1987.

LAZOTTI F., Lucía

Comunicación yisual y Escuela. Editorial Gustavo Gili, S.A., Barcelona, 1983.

NICOLAU, Dimitri, y otros

Las técnicas de la Imagen. Ediciones Mitre, Barcelona, 1982.

PRIETO, Daniel

\section{Biblioteca de Letras}

Análisis de mensajes. CHESPAL, Quito, 1988.

SALVAT

Teoría de la Imagen. Salvat Editores, S.A., Barcelona, 1973.

TAURINO, E., y otros

Comunicación de Masas: Perspectivas y Métodos. Editorial Gustavo Gili, S.A., Barcelona, 1978.

VERON, E., y otros

Lenguaje y Comunicación Social. Nueva Visión, Buenos Aires, 1969.

VILCHEZ, Lorenzo

Teoría de la imagen periodística. Ediciones Paidós, Barcelona, 1987. 